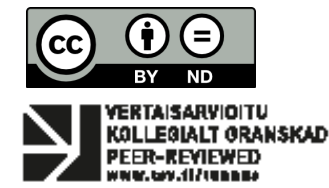

\title{
Holidaying behind the Iron Curtain: The material culture of tourism in Cold War Eastern Europe
}

\author{
Carys Wilkins, National Museums Scotland
}

\begin{abstract}
During the Twentieth Century, foreign travel underwent a process of democratisation. Increasingly, through the development of package holidays to ever more far-flung destinations, leisure tourism for the first time allowed ordinary people to experience different cultures first hand. With the increased availability and affordability of foreign travel, actively promoted by travel agencies with strong left-wing political affiliations and supported and facilitated by international friendship societies, the number of western tourists visiting Eastern Europe multiplied through the 1960s and 1970s despite the Cold War. This paper will explore western tourism in Eastern Europe during the Cold War in a Scottish context through the material culture of travel collected during this period, focusing on the collection of Miss Eileen Crowford (1913 - 1990) held by National Museums Scotland. Miss Crowford was a life-long Edinburgh resident and an avid collector. Her collection spans the 20th century and includes a significant collection of costume jewellery, mass-produced decorative arts and travel souvenirs. Drawing upon previously unresearched material in the archive and objects acquired on her travels, both items that she bought and things that she was given or obtained as part of the travel experience, provides a case study through which to explore engagement with communist culture and politics in a Scottish context. This paper discusses how these trips were being marketed to prospective Scottish travellers, and how souvenir production and distribution, as well as conditions of access, reflect an often-mediated experience of the Soviet East.
\end{abstract}

Keywords: Souvenir, Cold War, Friendship Society, Scotland, Eastern Europe.

\section{Introduction: The Souvenir and the Museum Collection}

This paper will explore Scottish tourism in Eastern Europe during the Cold War, through the material culture of travel collected between the mid-1950s and late 1970s, now held by National Museums Scotland (NMS). The archival study examines material in the Miss Eileen Crowford (1913 - 1990) collection and archive, focusing on souvenirs relating to her travels to Eastern Europe. The extensive collection, which is not currently on display in the museum, has previously been under-researched, particularly her travel and associated material culture, and remains virtually unknown outside of the institution. This paper investigates Crowford's patterns and categories of collecting, the role of memory and the function of the archive in tracing, framing and interpreting her souvenirs in the absence of the collector. In the context of this case study, an expanded definition of what constitutes a souvenir is useful, using a framework that encapsulates purchased objects intended as souvenirs, alongside ephemera and diaries with constructed meaning, using the tangible to unpack the intangible - memory. 
The souvenir turned museum object is often divorced from its context, its biography, its intended and acquired meaning for the individual who obtained it or received it as a gift. On entering the museum, the personal collection becomes fractured, individual items or groups of objects once a cohesive whole, are viewed in isolation. This process is exacerbated by the process of editing first by the collector then subsequently by the museum. The collection, broadly split into social history, decorative arts and archival all contain souvenirs.

This paper draws on the archive to fill in some of the gaps necessarily created by its status as a museum object and its shift from private to the public domain, whilst suggesting that even during the lifetime of the collector, the meaning ascribed to these souvenirs was not fixed. By examining the role of souvenirs in this context it provides a further opportunity, namely to interrogate the shift in meaning and function of these objects and their liminal status as souvenirs, subject to reclassification once they enter the museum collection. This case study provides a useful platform from which to examine how travel behind the Iron Curtain was packaged and marketed to foreign, specifically Scottish tourists and what these souvenirs can tell us about western travellers' experience of the communist east.

\section{Theoretical Framework and Literature Review}

Miss Crowford's collection has not previously been explored from the perspective of her travel or her souvenirs, rather being situated within broader narratives of consumption and mass production. Previous studies on souvenirs have centred on typologies (e.g., Gordon, 1986), which offer a helpful way to categorise souvenirs and describe their function, however they do not examine their potential meanings, and focus only on a narrow interpretation of what can be considered a souvenir. West's (2019) study of the collector Philla Davis, explores typologies and issues surrounding categorisation of souvenirs in a museum context, although it focusses on assigned meaning and value based on perceived levels of authenticity, suggesting that entering the museum fixes meaning. Miss Crowford left her collection to NMS as a bequest, whereas it is not known if Philla Davis intended her collection for a museum. This case study argues that the meaning of souvenirs continues to shift on entering the museum collection and the intention of the collector plays an important role.

Several studies examine purchase motivations and intentions as signs or markers of the travel experience, or as gifts (e.g., Belk, 1997; Gordon, 1986; Wilkins, 2011; Mars \& Mars, 2019; West, 2019). Some have explored purchase behaviour and the influence of age, gender or nationality on souvenir purchases (e.g., Kim \& Littrell, 2001; Wilkins, 2011). Miss Crowford's own purchase motivations and behaviours support the findings of this previous research, although her gift-giving contrasts with the literature, being bilateral in nature and extending beyond purchases made at the time of travel.

Other literature has focussed on the meanings of souvenirs, and how these meanings may change over time, although these are restricted to the domestic sphere (e.g., Love \& Sheldon, 1998; Collins-Kreiner, \& Zins, 2011; Masset, \& Decrop, 2021). Additionally, with the 
exception of Masset and Decrop (2021), they do not follow a longitudinal design through which to track the evolution of meaning. However, using the Crowford collection as a case study allows for an exploration of the meanings of souvenirs in a different context, a shift from domestic space to the museum, and over a longer period of time. Moreover, it provides a useful framework through which to explore western tourism to Eastern Europe during the Cold War era in a specific Scottish context which is largely absent from souvenirs literature, alongside evidence of wider engagement with communist culture and politics amongst the Scottish populace.

Studying the archive, and in particular the diaries, allows for an examination of her souvenirs and their meanings within the collection and in turn, shapes our understanding of Miss Crowford as a collector. Such a collection, particularly one belonging to a working-class collector rarely remains intact to the degree that has been retained in this instance, especially following the death of the collector, an issue described by Gerald and Valerie Mars (2019) in their study on Souvenir-gifts. Mars and Mars examine patterns of distribution following the death of the collector, yet here, the collection remains (ostensibly) intact, being inherited by an institution, rather than multiple familial recipients, offering an unique opportunity to explore meaning in both a private and public context. Whilst the scale of the collection presents a challenge in a museological sense, analysis of her travel offers a way, in the absence of the collector, to unpick the archive to identify her patterns of collecting, to reassign meaning to known souvenirs and to identify others.

\section{Approaching Miss Crowford's collection}

A keen collector, Miss Crowford frequently added to her collection - which spans the greater part of the 2oth century - with frugal purchases, recording acquisitions in diaries and meticulous lists. Her archive, presently 1800 registered items, includes a significant collection of costume jewellery, mass-produced decorative arts, kitsch, functional household items, ephemera and diaries, as well as souvenirs of her travels. It was the subject of an exhibition in 1990 highlighting the bequest (see Figure 1.), and a selection was displayed in the museum's permanent Art $\mathcal{E}$ Industry gallery until 2014 when the museum underwent a major redevelopment project. Here, the shift from private to public on entering the museum threatens the status of an object as a souvenir. Its context and location within the museum are changeable, shifting between the visible (on display) and invisible (in storage).

It was her jewellery collection that first drew my attention to her extensive travels and her interest in Eastern Europe. Numerous pieces appeared to be souvenirs from holidays abroad, but also within Scotland. Amongst the drawers of costume jewellery laid out in reference to Miss Crowford's cataloguing system - by colour and by type - were a small group of Soviet-era lapel badges, suggesting that she had travelled to Soviet Russia. Previously uncatalogued material in her paper archive proved her to be a fastidious record-keeper, although much of this material had become jumbled since entering the museum. Some remained unprocessed in storage and no longer associated with the material artefacts - the souvenirs. By its very nature, the archive itself is necessarily incomplete, shaped by proces- 
ses of editing by both the collector and the museum (Millar, 2010). In amongst the decades of payslips, bills etc, there was material relating to her travels: brochures, guidebooks and itineraries, often with annotations; correspondence with tour operators; payment schedules and lists of purchases; as well as additional souvenirs and other paper ephemera.

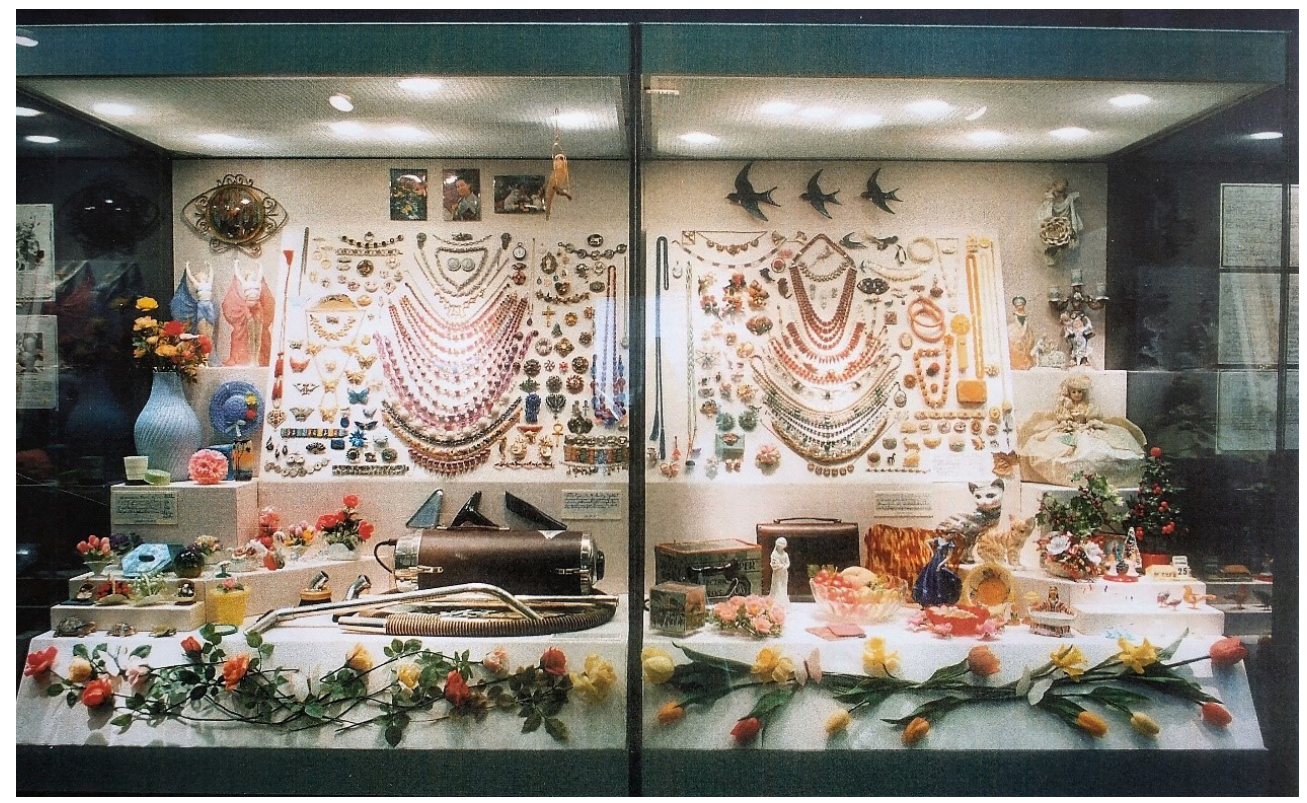

Figure 1. Miss Crowford Collects... [Exhibition] 21 November 1990 - 25 March 1991. (Photo: National Museums Scotland, ca. 1990).

Beyond the life of the collector, the meanings attached to the souvenirs remain fluid in the museum collection depending on how it is interpreted and the context in which items are displayed or kept in storage. There are limitations inherent in an archival approach, especially problems of memory, both in the record compiled by the collector and institutional memory in the context of the museum, resulting in gaps and inconsistencies in the record. In this way, her collection highlights some of the difficulties in categorising souvenirs in a museum context as alluded to by West (2019) in his discussion of the collection of Philla Davis. However, the merits of such an approach facilitate analysis of patterns of collecting and categorisation, recording and memory-making over several decades, not possible with an empirical study. In addition, the archival approach allows for a consideration of the 'after life' of souvenirs, that is the next phase of its object biography once it leaves the collector and enters the museum, which is largely missing from the literature.

The study involved a survey of all material concerning Crowford's travel to Eastern Europe and her engagement with communist culture and politics over a period of four decades, identifying trip destinations, the type, frequency and duration of these trips, their dates and the associated material culture retained and referenced within the collection. Display histories of the collection, and historic patterns of dispersal created by internal systems of classification for different types of material were examined to trace and connect 
disparate constituents of the collection which had become disassociated from one another and stored separately.

A comparative analysis examining the content of the diaries, lists and travel-related ephemera was undertaken to explore and identify her patterns and categories of collecting in relation to her travel based on the interrelationship between the archive, the souvenirs and the diaries. The use of a historical collection, particularly the use of the diaries within the methodological framework allows for a retrospective longitudinal approach over a period of time, not possible in a contemporary empirical study that necessarily requires a narrower focus. The methodology of using Miss Crowford's diaries provides valuable context for studying her souvenirs and travel experiences which would not otherwise be possible, although as Alaszewski (2006) suggests, they have traditionally been under-utilised in historical research as a data source.

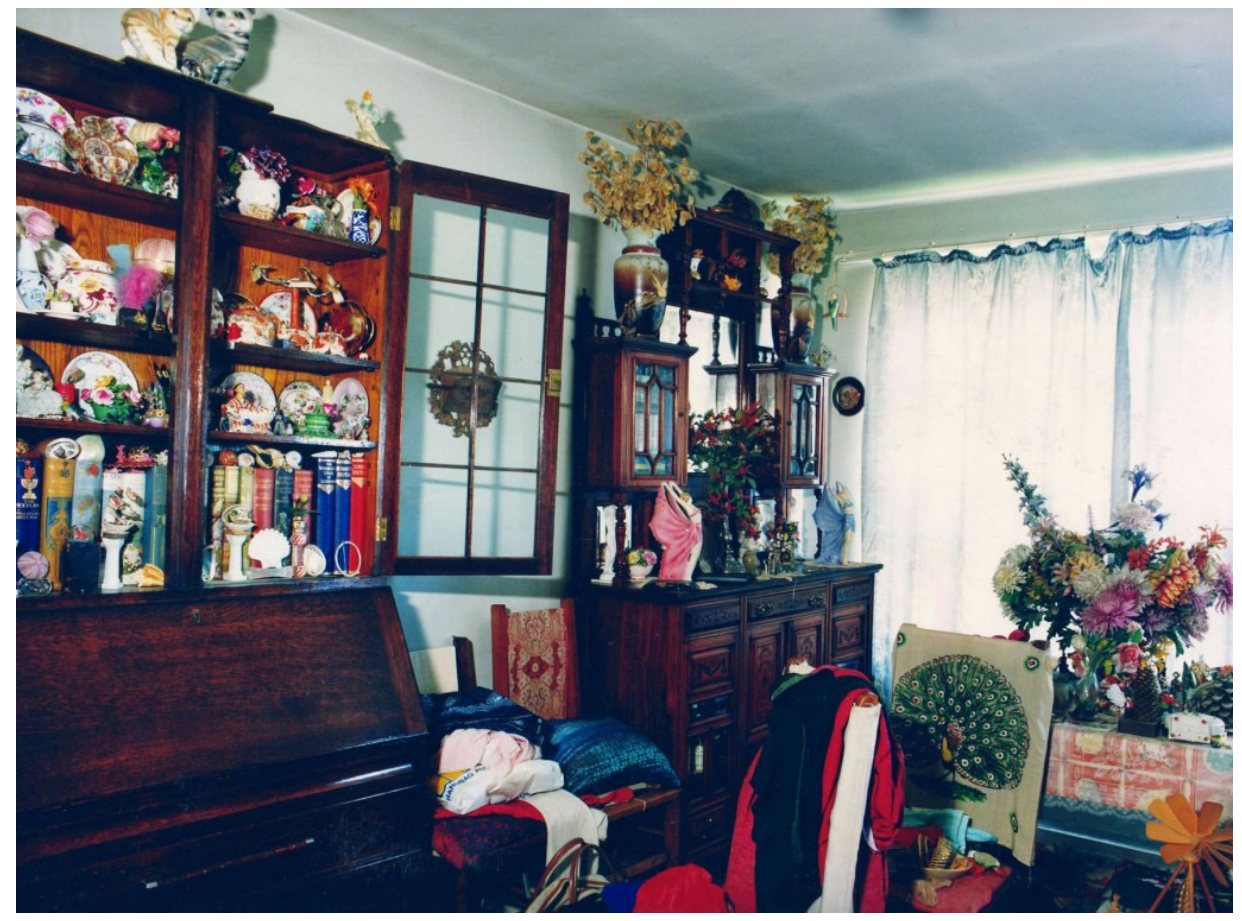

Figure 2. Inside Miss Crowford's Edinburgh Flat. (Photo: National Museums Scotland, 1990).

Eileen Crowford was born in 1913 in Edinburgh into a working-class family. She worked as a short-hand typist for Edinburgh City Council and remaining unmarried, lived with her parents until their respective deaths. Upon her death in 1990, she bequeathed her collection to NMS, then the Royal Scottish Museum, offering first refusal on the contents of her one bedroom flat (see Figure 2.). Her collection stands as an anomaly, with posthumous archives in museum collections typically relating to public figures, artists, designers or aristocratic collectors, often male. 
Miss Crowford travelled abroad from the early 1950 s to the early 1980 . Her travel to Eastern Europe alone during the Cold War era, included visits to the GDR, Romania, the USSR and Yugoslavia. Following her retirement in 1973, she travelled more extensively and with greater frequency, often as a solo traveller, part of a larger package tour group. This paper focuses on three main trips of interest: to East Germany in 1955, the USSR in 1973, and a later visit to the USSR in 1978, which also included Siberia and Central Asian Republics. These trips were selected as they represent three of the most comprehensive examples in terms of the context and available data provided by the paper archive, diaries and the material culture, both purpose-made tourist souvenirs, and materials subsequently ascribed meaning as souvenirs by the collector being obtained before, during and following the visits. In contrast, her travel to Romania is absent from the record in the diaries and her trip to Yugoslavia in 1981 afforded limited mention. The trips examined in this study are all group tours of a similar duration, organised by operators specialising in travel to communist countries and represent the start, peak and decline of Miss Crowford's foreign travels. Not only do these trips reflect her engagement with communist cultures, politics and even citizens in a specific Scottish context over a sustained period spanning half a century, but they also provide a platform to analyse patterns of collecting evident across her wider collection.

\section{Rediscovering Miss Crowford's travels}

The archive is evidence of her meticulous planning, especially involving her finances, found in both her diaries and her obsession with list-making on scraps of paper detailing budgeting minutiae. In both her approach to collecting and her personal filing, she certainly did not subscribe to a 'less is more' philosophy. Through her itemised daily expenditure, we know how much her trips cost, how much money she took with her, when and where she cashed travellers' cheques and for the most part what she spent it on. By looking at the travel itineraries, holiday brochures (where she highlighted the places she visited on optional excursions and listed the method of transport), her diaries and notebooks, we know where she went and how she chose to remember it. Her diaries are largely factual, resembling a daily planner in format rather than a descriptive travelogue. They nevertheless make it possible to contextualise her souvenirs and highlight her preference for small thrifty purchases, evident in her daily life too.

Whilst Miss Crowford kept a close eye on her day-to-day spending and clearly loved a bargain, the trips themselves were expensive when you consider that as of 1973 she was a pensioner living in social housing in the Edinburgh suburbs. Her 1978 trip to the USSR cost over $£ 400$ at a time when the average single person pension would have been around $£ 20 \mathrm{a}$ week. Moreover, this was her second trip that year, the first being a 14-day Mediterranean cruise, which included a port call at Alexandria and an excursion to Cairo and the Pyramids. 
The diaries, notebooks and loose lists offer an insight into her day to day life, documenting in real-time. Several diaries are evidently recycled with multiple retrospective entries collating important events, items of interest and lists of favourite things, over a period of several years or even decades. Although undated, these lists were themselves subject to later revision, with some entries crossed through. It is possible to interpret the souvenirs in this context, analysing collecting patterns and tracing the unstable nature of their status as souvenirs as meaning is ascribed and/or removed over time.

Within the paper archive, there is evidence of more concentrated reflection and retrospective additions in the 1970 and 1980s. Entries from 1980 onwards are identifiable owing to a marked shift in Miss Crowford's handwriting, coinciding with the stroke she suffered that year, followed by a second in 1984. Her foreign travel also tails off between these two dates. The diaries, notebooks and loose lists of purchases documenting, and relating to her travels can be viewed as souvenirs, serving as an aide-memoire which she revisited and re-evaluated at future dates, subject to revision and often summarising and collating information recorded elsewhere. A notebook dating from the 1970s (Crowford, 1973 - 1978) demonstrates this process of revision and consolidation through carefully arranged entries detailing the daily itineraries, travel arrangements, purchases and their respective costs for several trips taken over the course of the decade, including both trips to the Soviet Union. It is in these later entries that the function of the diaries and paper archives as mnemonic devices is consolidated, shifting in meaning to souvenirs. This shift points to the unstable nature of the souvenir, their meaning in flux during the lifetime of the collector and in its second life as a museum object.

What is clear, is that Miss Crowford, a life-long Russophile, had a longstanding interest in, and engagement with communist societies and their respective cultures and politics, which could be in part behind her motivation to visit Eastern Europe and the financial investment required to facilitate this. Her sustained engagement helps to both contextualise her souvenirs associated with her travel to Eastern Europe, as well as signalling additional layers of ascribed meaning compared to other travel souvenirs in the collection; the function of these particular souvenirs being tied to the political convictions of the collector, an association which would have been lost on entering the museum collection without the context that the archive provides. She often visited museums and libraries expanding her horizons, even teaching herself a little Russian. She writes the English translations under places of interest on many of her souvenir postcards, and there are attempts at using Cyrillic script in her diaries. The archive contains communist and left-wing literature and newspaper cuttings found in her home. Her diaries also point to strong communist-sympathies, noting visits by Soviet dignitaries to Scotland and criticism of anti-soviet reporting in the UK media. 


\section{Trip 1: GDR, August 1955}

In August 1955, Miss Crowford visited East Germany. This two-week organised tour is significant, as not only was it the first time she had visited a communist country, it was also one of the first coach tours arranged for western tourists since before the Second World War (Diamond, 1955). Her visit, six years before the construction of the Berlin Wall shows the early development of western tourism in East Germany, and a ready market within the UK. The trip which included East Berlin and the south of the GDR was organised by Progressive Tours Ltd, a London-based tour operator with known links to the CPGB which specialised in holidays to socialist countries (Roberts, 2000).

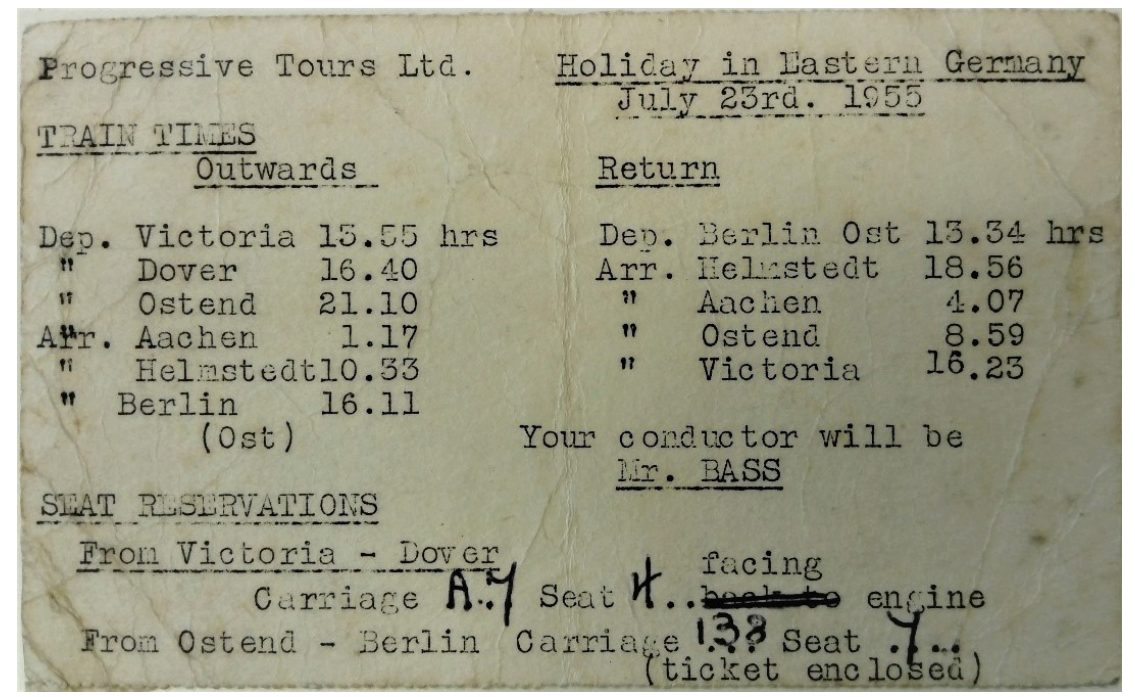

Figure 3. Progressive Tours Ltd., Travel Itinerary for Holiday in Eastern Germany 1955, Miss Crowford Archive, National Museums Scotland [W.MS.2017.23.78]. (Photo: National Museums Scotland/Author)

Miss Crowford's diary for the year (Crowford, 1955), reveals that she renewed her passport especially for this trip. The visa stamps in her passport, along with correspondence with the tour operator and travel itinerary (see Figure 3) reveal the regulations that travellers had to adhere to, including necessary documentation that needed to be completed before entry would be authorised. The material and ephemera associated with the trips seem to have been as important for her as the items she purchased, and as such can be viewed equally as souvenirs, having been retained and often annotated. The archive also serves to contextualise the material culture purchased and obtained during the trip: a plastic pin badge from Eisenach, entrance tickets to heritage sites, postcards and view-cards from Erfurt, Dresden, Leipzig, Naumburg and Potsdam. Nothing in the diaries tie these souvenirs to her GDR trip, instead, it is correspondence with the tour operator, passport visas and a handwritten list of hotels in East Germany in the archive which help identify and place them. Curiously, despite references in her 1955 diary before and following her visit, there are no entries for the dates of the trip itself.

Although specific mention of the souvenirs in the NMS collection is absent, diary entries following her return home indicate that she acquired souvenirs not only for her 
collection, but also as gifts for friends and acquaintances. Previous studies have explored the role of souvenirs as gifts (Kim, \& Littrell, 2001; Gordon, 1986), however, Miss Crowford's own use of souvenirs as gifts is more complex, their movement being bilateral in nature. Not only did she acquire souvenirs in the GDR intended as gifts for friends back in Scotland, she also purchased local souvenirs once she returned home as gifts for her new GDR correspondents unable to visit the UK.

While there are gaps in the archive, this trip is significant owing to the sustained contact Miss Crowford had with individuals she met in the GDR for at least 18 months following her return. Both letters and references in the diaries point to additional correspondence and gift exchange with several East German citizens whom she presumably met during her trip, including a Mr Hückel in Weissenfels and a Miss Forstmann in Berlin. She also corresponded with and sent Christmas cards to curators at museums she visited during her trip, in Sonneberg, Eisenach and East Berlin. It is here that we find the only photograph relating to her GDR trip, which pictures both Werner Hückel and Ruth Forstmann, along with a Mr Jüng, although this photograph was taken after she returned to Scotland and enclosed in a letter from Ruth Forstmann, in which she describes plans to visit the UK (Forstmann, 1955). Photographs from the trips themselves are rare and none exist in the archive from the three trips discussed in this paper.

We also see a continued engagement with literature sympathetic to the aims of the East German state. Contemporary left-wing newspapers of the day provided a vehicle through which to promote travel to the GDR through first-hand accounts of western tourists who visited. In the archive is a cutting from Democratic German Report (DGR), the bi-weekly English-language newsletter produced from 1952 to 1975 and edited in Berlin by British Journalist John Peet who defected to the GDR in 1950 (Berger \& Laporte, 2004). The cutting from September 1955, a month after Miss Crowford's trip, features an article by CPGB member Dorothy Diamond a regular traveller to the GDR who frequently wrote articles in publications supportive of East Germany (Berger, \& Laporte, 2010). The article includes an account of the tour earlier that year by an unnamed participant:

This year, for the first time, ordinary tourists from Britain were able to visit the German Democratic Republic on trips organised by Progressive Tours Ltd - we saw town and country, with treasures of history and triumphs of new building, and sometimes both together, as in the growing construction of Dresden from ashes and shattered stones (Diamond, 1955).

Whilst it is unclear whether the anonymous reviewer was on the same tour as Miss Crowford, they appear to have followed a similar itinerary, with visits to towns and cities with historic medieval centres, well established as tourist sites prior to the Second World War, including museums, places of worship, and other points of interest reflected in the souvenirs. Neither the souvenirs nor the archive explicitly allude to any excursions aimed at promoting the new communist state. However, annotations to the DGR article in Miss Crowford's hand underlining places and points of interest suggest otherwise, as she typically highlighted places visited on her trips. 
Miss Crowford's next visit to the Eastern Bloc was in August 1973, on a two-week trip to the USSR, where she visited Moscow, Kiev and St. Petersburg (then Leningrad). Her daily itinerary lists visits to museums and galleries, the theatre, places of worship, the circus, shopping and general sightseeing. She collected postcards from all three cities, both general view-cards as well as examples relating to heritage sites she referenced in her diaries, such as the Hermitage and Peterhof fountains. In addition, she collected three badges, stone carvings, a Palekh lacquer work diary and two decorative wooden boxes. Alongside the badges, only one of the wooden boxes and single stone carving, have been positively identified in the NMS collection, suggesting that she potentially reconsidered and accordingly edited her collection, or that some of these items were intended as gifts. The importance of the archive rests in the interplay between its constituent parts, ascribing meaning to the souvenirs and building a picture of Miss Crowford as the collector which would not be possible otherwise. The process of editing and shifting subjectivities both by the collector and the custodians of the museum collection continues, with the meanings assigned to the souvenirs continually constructed and reconstructed as Love \& Sheldon (1998) suggest.

The trip was organised by Sovscot Tours Ltd, a Glasgow-based tour operator founded by the Scotland-USSR Society in 1961, which enabled thousands of Scottish tourists to travel directly from Scotland to the Soviet Union, both by air and sea (Royle, 2019). The Society was instrumental in actively promoting tourism in the USSR within Scotland, distributing holiday brochures, soviet publications and other literature to members, schools and other interested parties (Scotland-USSR Society, 1949 - 1985). Moreover, they were in discussions with Intourist ${ }^{1}$ as early as 1947 about the "resumption of ordinary tourist facilities" (Scottish-USSR Society, 1947). Two years prior to setting up Sovscot, the Society successfully organised the first post-war Scottish tourist group to the USSR. The group of 57 Scots spent 10 days on soviet boats, calling in at Baltic ports, and nine days in Leningrad and Moscow (Scotland-USSR Society, 1957 - 1959). Sovscot sent Scottish tourists to the USSR throughout the Cold War and by the 1980 os the operator was sending between two and three thousand Scottish tourists annually (Scotland-USSR Society, 1949 - 1985).

Direct routes from Scotland offered not only convenience for prospective Scottish tourists but promised savings too. A travel feature in The Glasgow Herald a year before Miss Crowford's own trip, notes that group tours departing Glasgow on chartered Russian flights were "less expensive than comparable tours originating in London" (Brooke, 1972, p.5). Miss Crowford flew directly from Leningrad to Prestwick, near Glasgow on her return from her 1973 trip (Crowford, 1973 - 1978). Holidays departing from Glasgow, Edinburgh and London marketed by Sovscot Tours Ltd, and other tour operators were advertised widely in the popular press, including Scottish Daily Newspapers: The Glasgow Herald (Clark, 1979; Sovscot Tours Ltd., 1972, 1978) and Evening Times (Black Sea Holidays, 1977; Sovscot Tours Ltd., 1976). Reviews of trips and travel features on East European destinations offered practical

1 Intourist has served as the principal travel operator for foreign tourism within Russia since it was founded in 1929. Until it was privitised in 1992, it was responsible for managing and facilitating foreign travellers' access to and travel within the wider Soviet Union. 
advice for travellers and described the types of trips available including solo travel options and camping, as well as beach holidays at Black Sea resorts promoted as viable alternatives to popular coastal destinations in western Europe (McDowell, 1960; Richardson, 2016; Starks, 1972). Some sought to manage travellers expectations as to the reality of travel behind the Iron Curtain. As one journalist warned "The milieu in the Iron Curtain countries differs from that of the Mediterranean countries. Both the philosophy and atmosphere are different, and tourism does not develop overnight" (Brooke, 1972, p.5). Not all reviews were positive, with many emphasising safety and hygiene concerns, with reports of hotels with blocked fire escapes, dirty rooms and entire tour groups struck down with dysentery-like symptoms (Ratcliffe, 1977; McCallum, 1983)

Travel agencies across Western Europe commonly affiliated with western labour movements and friendship societies (Pedersen, 2018), partnered with Intourist through necessity rather than choice, given the monopoly this state organisation enjoyed over foreign tourism to the Soviet Union. Whilst Intourist had a presence in the UK from 1938 (Richardson, 2016), it was in the post-Stalin era that they began marketing packages to prospective travellers on a significant scale (Vladimir boosts Russia's cheap holidays, 1961). The signing of cultural agreements with several western countries in 1956, including Britain in 1957, marked a shift in policy towards increased contact with the West, including developing and encouraging international tourism on a greater scale (Richmond, 2003).

The integral role of Intourist is evident in the Crowford archive, both in published brochures and city guides, often annotated, and the ephemera she collected documenting her hotel stays, including Intourist-branded luggage labels and hotel cards. This material is an important component of the travel-related material she collected and thus treated as souvenirs and provides a wider context through which to understand the tourist experience of travel to Eastern Europe during the Cold War in a Scottish context. The importance of the ephemera emphasises the need to expand the definition of what can be classed as a souvenir as explored by Collins-Kreiner \& Zins (2011), whose study frames a broader definition of souvenirs to include any material that reminds the collector of their trip regardless of when it was acquired or if it was intended to function as a souvenir. In the Crowford collection, both types of material fulfil a similar function and in the museum collection, their meaning is intrinsically connected through the archive.

Sovscot Tours Ltd began operating as a wing of the Scotland-USSR Friendship Society. The Society attracted many influential supporters representing all aspects of Scottish cultural life (Scotland-USSR Society, 1985). Miss Crowford was herself an early member of the Society. There were opportunities for members to meet groups of soviet visitors hosted by the Society, as well as countless occasions to hear first-hand accounts from fellow Scots who shared their own holiday experiences (Scotland-USSR Society, 1949 - 1985). The Society was also pivotal in fostering and arranging cultural exchanges, including groups of performers from across the USSR touring multiple Scottish venues and reciprocal visits for Scottish performers, primarily promoting folk culture. Diary entries, correspondence from the Society and annotated souvenir programmes (see Figure 4) reveal that Miss Crowford 


\section{Carys Wilkins}

attended several Society-organised cultural activities such as concerts in the 1940 os and 1950 .

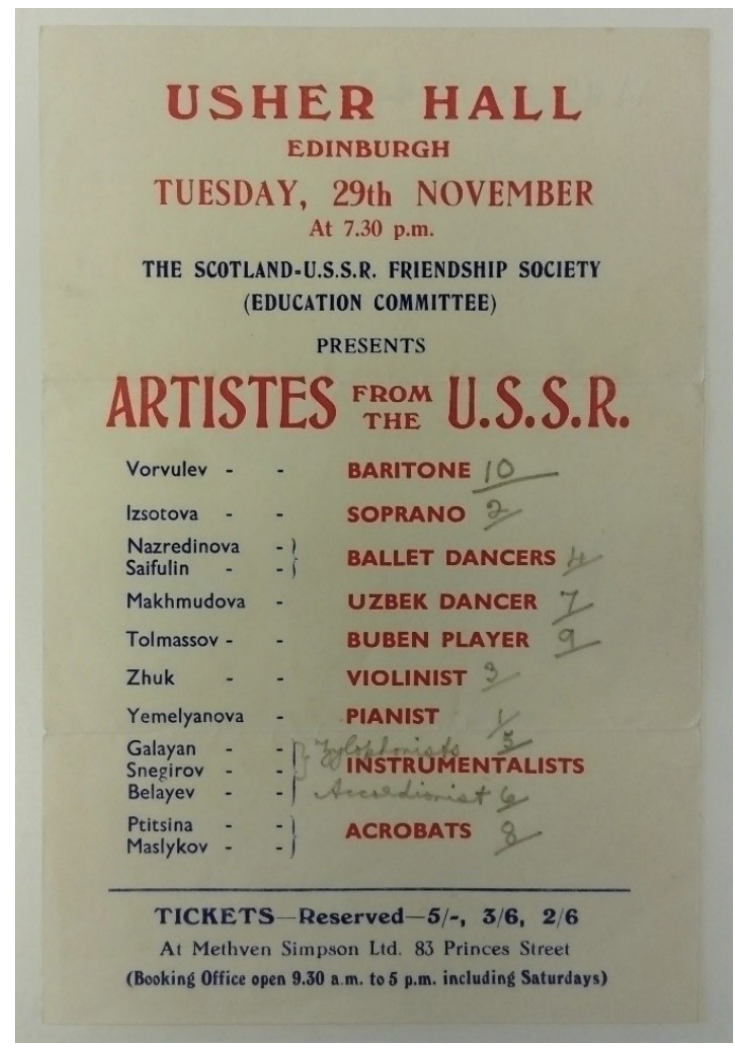

Figure 4. Playbill, Scotland-USSR Society Concert, by unknown designer, Miss Crowford Archive, National Museums Scotland [W.MS.2017.23.38]. (Photo: National Museums Scotland/Author)

Concert tours and temporary exhibitions allowed the Society to reach an audience beyond its limited membership, introducing the Scottish public to various aspects of soviet culture. Films too were an important cultural and educational tool to convey positive messaging about the Soviet Union (Murray, 1950). From its outset, the Society actively advocated for regular screenings of soviet films, even exploring the option of purchasing a cinema for such purposes. Miss Crowford references having watched a variety of Soviet films, including features, documentaries and newsreels, demonstrating her long-term engagement with Soviet culture and politics in the decades prior to her first visit to the USSR.

\section{Trip 3: USSR, Siberia and Soviet Central Asia, May 1978}

Her two trips to the USSR, in the early and late 1970s, shows the continued opening up of the USSR to foreign tourist markets through package holidays, marketing trips that were broader in their offering both geographically and culturally. The quantity of Intourist brochures and guidebooks in the archive, illustrate the marketing of these expanded packages enabling greater access to both the Russian interior as well as Central Soviet States, 
and to Miss Crowford's desire to return. The brochure detailing her Explorers Holiday in Soviet Central Asia and Siberia, is one of 11 themed holiday categories available for 1978, offering 18 different 15-day tour itineraries to suit every taste (Intourist Moscow Ltd., ca. 1977). Along with the obligatory visits to Moscow and Leningrad at either end of her trip, her 1978 tour took her to Bratsk, Irkutsk, Tashkent and Samarkand, with transfers through Omsk, Novosibirsk and Alma-Ata. This second trip, included more varied excursions (Crowford, 1973 - 1978), such as a visit to a wood pulp factory outside Bratsk, a kindergarten and local village near Irkutsk, as well as engineering projects such as the Angara dam, and archaeological sites, Islamic places of worship and mausoleums in Tashkent, Samarkand and Penjikent.

In terms of souvenir collecting, she did not deviate from her standard established categories and patterns of collecting, categories also apparent in her wider collection of souvenirs from other trips, both domestic and foreign. Following a purely functional approach, her souvenirs can be sorted into three of the five broad categories described by Gordon (1986), namely 'Pictorial images', 'Markers' and 'Local products'. Her collecting, both during and in preparation for her trip, can broadly be split into the following categories: Jewellery, specifically small metal and enamel lapel badges; postcards and view-cards; ornaments and local handicrafts, including two examples produced at the State-run Leningrad Lomonosov Porcelain Factory; and travel-related paper ephemera. They are largely mass-produced and obtained for a relatively low price point for goods marketed primarily at or made available to foreigners. Furthermore, they can be characterised by their small scale, albeit arguably for practical reasons as they would have been easily portable.

Many of these souvenirs had lost their meaning as well as their function as souvenirs on entering the museum collection. Without context and the layered interpretation afforded by the archive, many of the souvenirs are ostensibly unremarkable. Yet, this broadly points both to Miss Crowford's personal collecting preferences, but also to the homogenous nature of the available material culture afforded to foreign tourists across the Soviet Union, with little local variation even in Soviet Central Asia, or rather if there was, she did not collect it. Instead, souvenirs acquired during her visit are supplemented with travel ephemera and material in the archive, obtained prior to and during the trip. Whilst some items were produced as souvenirs with foreign tourists the intended consumers, others had that value assigned to them by Miss Crowford. Whilst the content pictured in the postcards, the designs of the souvenir 'Baikal' and 'Samarkand' lapel badges and her purchase of local handicrafts in Uzbekistan reflect the geographical shift to Siberia and Soviet Central Asia, away from the western centres of Moscow and Leningrad, they still fall into the four aforementioned categories.

Miss Crowford collected soviet badges on both her trips to the USSR. These demonstrate the extraordinary range of this type of mass-produced souvenir, which had a firmly established domestic market by the time of her first visit in 1973 when she acquired three examples, followed by a further nine in 1978. The craze for manufacturing and collecting lapel badges, known in Russian as znachki within the Soviet Union serves as an example of a 
pre-existing local material culture being shared with foreign tourists either as purpose-made souvenirs, or made available via an often-unregulated secondary market. Znachki were bought by and gifted to foreign tourists and could also be bartered in exchange for goods such as chewing gum, though Miss Crowford appears to have purchased all her examples, and the scale of the collecting craze did not escape the attention of the foreign press (Smith, 1974). Although brief, her diary entries and loose lists often list only the type of object such as a badge, we know where and when she bought these items and how much for, making it possible for the most part to match up individual items with specific legs of her trips, and visits to points of interest.

The small-scale of the znachki, their ubiquity and low price-point, and their ready assimilation into Crowford's established collecting categories made them an obvious choice of souvenir. Her examples also serve to illustrate and contextualise the development of a souvenir and collectables culture within the Soviet Union which took off in the postStalin era and was encouraged through official channels, initially aimed at a domestic market but which also found a ready audience amongst foreign tourists. The sheer prevalence of znachki, across the Soviet Union, numbering tens of thousands of unique designs was matched only by public demand and their widespread appeal as collectible consumer goods, and unlike another popular collectible - stamps - they were not subject to tightly state-controlled production and distribution (Lewis, 2011).

The creation of znachki dates back to 1722, however designs and production were limited, their use restricted to official events, and post-Revolution personal collecting was strongly discouraged (Lewis, 2011). However, the early 196os witnessed a shift in Soviet policy, coinciding with a programme of de-Stalinisation, leading to a relaxation of restrictions which officially sanctioned and even encouraged individual collecting for the first time (Grant, 1995, as cited in Lewis, 2011). This move coincided with the Soviet space programme and marked a change in the use of znachki as souvenirs of Soviet achievements and as symbols of mass participation. Whilst early examples tended towards simplicity, with little variation in design and typically a single colour of enamel on metal, the new status of znachki as souvenirs witnessed an explosion in both scale of production and diversity of available designs (Lewis, 2011).

Whilst there are no examples of Space Race znachki in the Crowford collection, her examples illustrate the diversity of designs being produced by the 1970s. Lewis (2011) cites three principal categories of znachki: memorial, jubilee and souvenir. Miss Crowford collected znachki from all three categories, but primarily from the latter. Her memorial and jubilee pins mark the anniversary of the October Revolution and dedications to the memory of Lenin. The souvenir examples are from a variety of sources, featuring museums, heritage sites and points of interest, municipal coats of arms for Samarkand, Gorbatov, Pochinki, Rostov-Veliky and even a badge produced for the youth division of the Water Rescue Society known as the 'Young Osvodovets' (see Figure 5).

The task of supplying tourists with souvenirs posed a problem for Intourist, requiring resources that they simply did not have at their disposal and apathy on the part of manu- 
turers given the level of investment required. As 'luxury' products, mass-produced souvenirs for foreign tourists were a low priority (Hazanov, 2016). Miss Crowford appears to have purchased the majority of her souvenirs either at heritage sites such as museums, or from Beriozka stores, often located within the Intourist hotels she stayed in. Travellers cheques too were cashed at Intourist Hotels. Beriozka stores were a chain of state-run retail shops in the Soviet Union in existence between the late 1950 and late 1980 s which sold goods to foreigners in exchange for foreign 'hard' currency or special vouchers available to select soviet citizens (Ivanova, 2013). Beriozka shops, catering primarily to tourists, offered souvenirs alongside luxury goods not readily available to the average soviet populace (Browne, 1975; Levitas, 1983). The diaries and associated lists of expenditure from both trips to the USSR, tell us that she used both local and foreign currency to acquire souvenirs suggesting that only certain things were obtainable to foreigners using local currency.

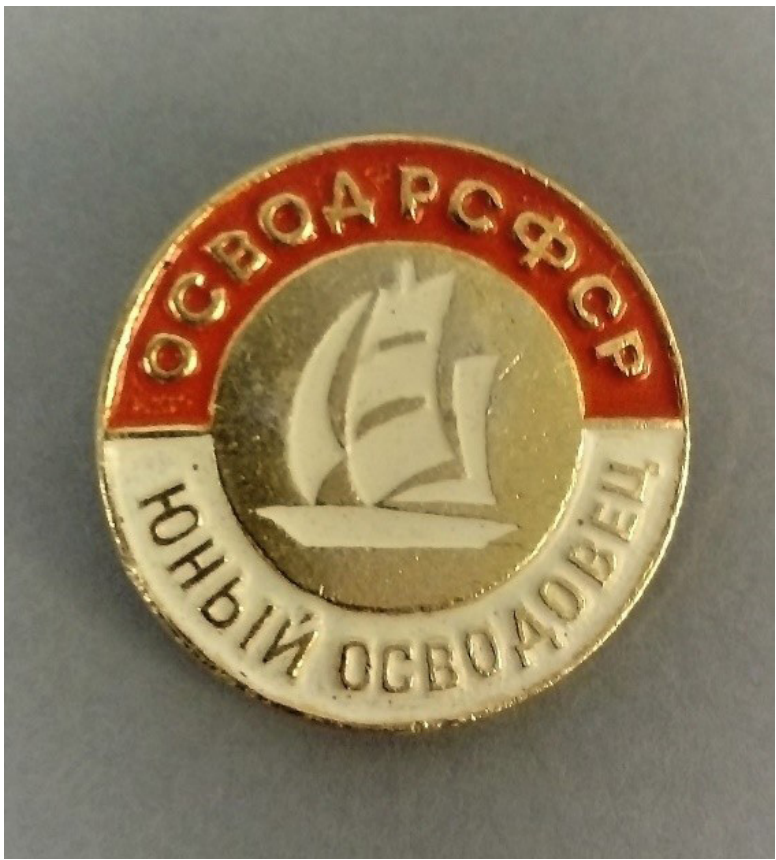

Figure 5. OSVOD enamel and metal lapel badge, by unknown designer, Miss Crowford Collection, National Museums Scotland [A.1990.1176]. (Photo: National Museums Scotland/Author)

\section{Conclusions}

This case study provides a useful framework through which to specifically explore Scottish tourism to Eastern Europe during the Cold War, which is largely absent from souvenirs literature, and the role of friendship societies in promoting and facilitating both cultural engagement and travel to communist countries. Previous studies have centred on typologies (Gordon, 1986), on purchase motivations (Belk 1997; Gordon 1986; Wilkins 2011; West, 2019), on purchase behaviour (Kim \& Littrell, 2001; Wilkins, 2011), and the meanings of souvenirs (Love \& Sheldon, 1998; Collins-Kreiner, \& Zins, 2011; Masset, \& Decrop, 2021). 


\section{Carys Wilkins}

However, using the Crowford collection as a case study and the use of diaries as a methodological framework allows for an exploration of the meaning(s) of souvenirs as they shift from private to public collection and help shape our understanding of Miss Crowford as a collector. Moreover, it explores her collection from a new perspective, using the diaries and paper archive to reconstruct her travel experiences, souvenirs collection and sustained engagement beyond the duration of her trips. The scale of the collection, its relative completeness combined with the socio-demographic variables of the collector are unusual in a museological context. In the absence of the collector, an analysis of her travel makes it possible to identify patterns of collecting, to accord meaning to known souvenirs and to discover others.

Miss Crowford's collecting activity spans the breadth of material accumulated in the lead up to, during, and following her various trips and provide evidence of continued engagement and reflection once she had returned home, often over a long period. The annotated lists, notebooks, summaries and retrospective diary entries reflect a continual process of memory recording and archiving, drawing attention to events and objects that continued to hold great importance for her.

Her first trip to the GDR is significant given its early date, showing the early development of a tourism market for westerners. Her two trips to the USSR, in 1973 and 1978, alongside the material she collected and retained and the accompanying ephemera in the archive, reflects the continued opening of the USSR to foreign tourists beyond the western urban centres of Moscow and St. Petersburg or the Black Sea resorts. Her second visit points to an expanded offering and availability of package trips which were broader both geographically and culturally, and to the relative lack of variation in the types of souvenirs that were made available in satellite locations.

From her diaries, we know what she collected, including items in the collection and archive not previously identified as travel souvenirs, even if it has not yet been possible to positively identify and date some items owing to the lack of detail in the lists and diary entries, or in some instances, we no longer have the physical objects. The diaries provide context for the physical items of material culture collected, both items that she bought and things that she was given or obtained as part of the travel experience. They also point to the range of material that was made available for foreign tourists and the conditions of access, including the requirement for hard currency to obtain many souvenirs via points of exchange such as the Beriozka stores. This allows us an insight into her collecting practices over a number of decades, and several patterns come to light.

What emerges is a similar vein of collecting, in terms of the types or categories of souvenirs that relate both to the trips described in this paper, as well as to those outwith Eastern Europe (both domestic and international) namely jewellery, postcards, ornaments and paper ephemera. Photographs from her travels are rare, which perhaps explains her fondness for collecting items and ready-made images that were made available to her to remember her trips. Cross-referencing material in the archive with material artefacts highlights some inconsistencies and gaps, whereby some of the souvenirs referenced in the archive are 
absent from the collection. Some were distributed as gifts to friends and acquaintances during her lifetime, as is evident in her 1955 diary which details souvenirs acquired by Miss Crowford as gifts and their respective recipients; others may have been subject to a similar process of revision and consolidation as is evident in the written record.

The souvenir turned museum object is often detached from its original context and intended meaning or meanings ascribed and attached to it by the collector who acquired it or the individual who received it as a gift. In the museum context, the collector's hand becomes obscured as the personal collection is fractured through hierarchies of categorisation, separating objects by material and type and distinct from the archive. Here, the Crowford archive fills in some of the gaps necessarily created once the souvenir shifts from private to public realm on entering the museum collection, making it possible to some degree to trace and redefine these items as souvenirs.

\section{References}

Alaszewski, A. (2006). Using diaries for social research. SAGE Publications Ltd

Belk, R. W. (1997). Been There, Done That, Bought the Souvenirs: Of Journeys and

Boundary Crossing." In S. Brown \& D. Turley (Eds.), Consumer Research: Postcards from the edge (pp. 22-45). Routledge.

Berger, S., \& Laporte, N. (2010). Friendly enemies: Britain and the GDR, 1949/1990. Berghahn Books.

Berger, S., \& Laporte, N. (2004). John Peet (1915-1988): An Englishman in the GDR. History, 89(293), 49-69. https://doi.org/10.1111/j.0018-2648.2004.00287.x

Black Sea Holidays. (1977, February 5). Bulgaria the beautiful. The Glasgow Herald, 8.

Brooke, M. (1972, January 4). A choice that stretches from Pole to Pole. The Glasgow Herald, 5.

Browne, M. W. (1975, September 9). Black Markets Bloom in Eastern Europe Behind Facade of StraitLaced Marxism. New York Times. https://www.nytimes.com/1975/o9/o9/archives/black-marketsbloom-in-eastern-europe-behind-facade-of-straitlaced.html

Clark, W. (1979, February 5). Rush is on as Scots seek hot new spots. The Glasgow Herald, 10.

Collins-Kreiner, N., \& Zins, Y. (2011). Tourists and souvenirs: changes through time, space and meaning. Journal of Heritage Tourism, 6: 1, 17 - 27. http://dx.doi.org/10.108o/1743873X.2010.515312

Crowford, E. (ca.1942). [Diary 1942, with later entries from 1942 - 1954]. Miss Crowford Archive (W.MS.2011.122.49), National Museums Scotland, Edinburgh, UK.

Crowford, E. (1955). [Diary 1955]. Miss Crowford Archive (W.MS.2011.122.63), National Museums Scotland, Edinburgh, UK.

Crowford, E. (1973 - 1978). [1970s travel notebook]. Miss Crowford Archive (W.MS.2011.122.70), National Museums Scotland, Edinburgh, UK

Diamond, D. (1955, September 30). Tourist in Democratic Germany. Democratic German Report, Newspaper cutting from the Miss Crowford Archive (W.MS.2017.23.79), National Museums Scotland, Edinburgh, UK.

Forstmann, R. (1955, December 31). [Letter to Miss Crowford]. Miss Crowford Archive (W.MS.2017.23.80), National Museums Scotland, Edinburgh, UK.

Gordon, B. (1986). The Souvenir: Messenger of the Extraordinary. Journal of Popular Culture 20 (3): $135-46$. 


\section{Carys Wilkins}

Hazanov, A. H. (2016). Porous Empire: Foreign Visitors And The Post-Stalin Soviet State [Doctoral dissertation, University of Pennsylvania]. Publicly Accessible Penn Dissertations. 2330. https:// repository.upenn.edu/edissertations/2330

Intourist Moscow Ltd. (ca. 1977). Welcome to the Soviet Union 78, Magnolia Summer Tours [Brochure]. Miss Crowford Archive, National Museums Scotland, Edinburgh, UK.

Ivanova, A. (2013). Shopping in Beriozka: Consumer Society in the Soviet Union. Zeithistorische Forschungen - Studies in Contemporary History, 10(2), 243-263. https://doi.org/10.14765/zzf.dok1534

Levitas, G. (1983, July 3). Shopper's World: Capitalist's Guide to Beriozkas. New York Times. https:// www.nytimes.com/1983/07/03/travel/shopper-s-world-capitalist-s-guide-to-beriozkas.html

Lewis, C. S. (2011). From the Kitchen into Orbit: The convergence of Human Spaceflight and Khrushchev's Nascent Consumerism. In J. Andrews \& A. A. Siddiqi (Eds.), Into the cosmos: Space exploration and Soviet culture (pp. 213-239). University of Pittsburgh Press.

Love, L. L., \& Sheldon, P. S. (1998). Souvenirs: Messengers of Meaning. Advances in Consumer Research, 25, 170-75.

Kim, S., \& Littrell, M. A. (2001). Souvenir Buying Intentions for Self versus Others. Annals of Tourism Research 28 (3): 638-57.

Mars, G., \& Mars V., (2019). ‘Souvenir-gifts’ as Tokens of Filial Esteem: The Meanings of Blackpool Souvenirs. In M. Hitchcock \& K. Teague (Eds.). Souvenirs: The Material Culture of Tourism (pp. 91-111). Routledge.

Masset J., \& Decrop A. (2021). Meanings of Tourist Souvenirs: From the Holiday Experience to Everyday Life. Journal of Travel Research. 6o(4):718-734.

McCallum, A. (1983, August 11). Illness probe launched after Russian tour. The Glasgow Herald, 5.

McDowell, R. (1960, February 6). Talking of Holidays, The Glasgow Herald, 12.

Millar, L. (2010). Archives : Principles and practices (Principles and practice in records management and archives). Facet.

Murray, T. (1949, January 12). Special Memorandum. Thomas Murray Papers (Acc. 9083 Box 5/5), National Library of Scotland, Edinburgh, UK.

Murray, T. (1950, February 23). Films of the USSR [Memorandum] Thomas Murray Papers (Acc. 9083, Box 5/1), National Library of Scotland, Edinburgh, UK.

Pedersen, S. (2018). Eastbound tourism in the Cold War: the history of the Swedish communist travel agency Folkturist, Journal of Tourism History, 10(2), 130-145. https://doi.org/10.1080/175518 2X.2018.1469679

Ratcliffe, W. A. (1977, March 2). Intourist and fire risks, The Glasgow Herald, 6

Richardson, D. (2016). Let's go!: A history of package holidays and escorted tours. Amberley Publishing.

Richmond, Y. (2003). Cultural exchange \& the Cold War: Raising the iron curtain. Pennsylvania State University Press.

Roberts, J. (2000). Speak clearly into the chandelier: Cultural politics between Britain and Russia, 1973-2000. Curzon.

Smith, H. (1974, September 22). Pin Hobby, Soviet Fad, Is Criticized. New York Times. https://www. nytimes.com/1974/o9/22/archives/pin-hobby-soviet-fad-is-criticized-millions-to-be-producedbadges.html

Scotland-USSR Society: (1947). Executive Committee Minutes [Report] Thomas Murray Papers (Acc. 9083, Box 5/3), National Library of Scotland, Edinburgh, UK. 
Scotland-USSR Society. $(1949-1985)$. Annual Reports. Records of the Scotland-USSR Society (TD1125/2/1), Mitchell Library, Glasgow, UK.

Scotland-USSR Society. (1957 - 1959). Report of the National Council of the Scotland-U.S.S.R. Friendship Society 1957-1959. [Report] Records of the Scotland-USSR Society (TD1125/2/1), Mitchell Library, Glasgow, UK.

Scotland-USSR Society (1985). Scotland-USSR Society 1945-1985: A Brief Account [Brochure] Records of the Scotland-USSR Society (TD1125/7), Mitchell Library, Glasgow, UK.

Sovscot Tours Ltd. (1972, December 30). Caucasus Tours. The Glasgow Herald, 8.

Sovscot Tours Ltd. (1976, January 26). Go somewhere Different. Go from Glasgow. Evening Times, 2.

Sovscot Tours Ltd. (1978, September 12). For your Autumn break book October holidays in the U.S.S.R. The Glasgow Herald, 4.

Starks, M. J. (1972, January 4). Doing your own thing on the Soviet scene. The Glasgow Herald, 7.

Vladimir boosts Russia’s cheap holidays. (1961, September 21). Evening Times, 2.

West, A. (2019). Transformations of the Tourist and Souvenir: The Travel and Collections of Philla Davis. In M. Hitchcock \& K. Teague (Eds.), Souvenirs: The Material Culture of Tourism (pp. 112-126). Routledge. 1 Intourist is the Soviet travel agency that arranged foreign travels 